\title{
Public Transportation Development in Surakarta City in Partnership Governance Perspective
}

\author{
Kristina Setyowati ${ }^{1}$, Salsabila Almas Nadhifa ${ }^{2}$, \\ Retno Suryawati ${ }^{3}$, Priyanto Susiloadi ${ }^{4}$ \\ 1'Department of State Administration, Universitas Sebelas Maret, Indonesia (email: kristina@staff.uns.ac.id) \\ 2Department of State Administration, Universitas Sebelas Maret, Indonesia (email: salsabilaalmas69@gmail.com) \\ ${ }^{3}$ Department of State Administration, Universitas Sebelas Maret, Indonesia (email: retnosuryawati@gmail.com) \\ ${ }^{4}$ Department of State Administration, Universitas Sebelas Maret, Indonesia (email: priyanto_map@yahoo.com)
}

\begin{abstract}
Transportation plays an important role in mobility in urban areas. Surakarta City provides Bus Rapid Transit (BRT) transportation system, Batik Solo Trans. This research aims to find out the partnership performed by Surakarta City in public transportation development in partnership governance perspective. Data collection was conducted through interview and documentation. Analysis was conducted using Successful Collaborative Partnership principle from Agarwal, Caiola, and Gibson (2015). The research took place in Surakarta City, particularly in PT. Bengawan Solo Trans, PT. Trans Global Mandiri, Transportation Office, and Technical Executive Unit for Transportation as the organizer of feeder along with Bersama Satu Tujuan Cooperative. The research method used here was qualitative one with descriptive approach. The result of research shows that the principle of Successful Collaborative Partnership is analyzed based on 4 principles: (1) Clear Goals: to improve public service safely, comfortably, and affordably to the public; (2) Clear Roles: Government contributes to formulating policy, funding "buy the service" program, licensing, and providing public transportation infrastructure. The private is the operator responsible fully for public transportation management; (3) Trust: Surakarta City government trusts fully the private to perform cooperation, to provide and to manage Batik Solo Trans and feeder bus service; and (4) Commitment: Government and Private are committed mutually to providing transportation infrastructure, managing, maintaining, and operating public transportation.
\end{abstract}

\section{Keywords:}

batik solo trans; transportation office; partnership governance; public transportation

\section{Introduction}

Indonesia is a state with population growth due to urbanization. It has an implication to such urban issues as increased population number, urban infrastructure, and mobility. High urban mobility not compensated with good infrastructures will lead to traffic jam. 
Transportation plays an important role in urban mobility. To urban with the large number of populations, providing public transportation can be one of controlling strategies applied because public transportation can accommodate larger population mobility (Dinas Perhubungan NTB [Transportation Office of NTB], 2020). City government should be responsible for the emergence of urban issue complexity. The government should take improvisation measures in public service, with comprehensive and integrative approach, the one that can accommodate all urban problems.

As one of urban regions in Indonesia, Surakarta City is an agglomeration area along with Boyolali, Sukoharjo, Wonogiri, Sragen, and Klaten. This city is not as big as other cities in Indonesia, have only $44.04 \mathrm{~km}^{2}$-wide area. It is not proportional to the number of populations reaching 2,000,000 people in the afternoon. Meanwhile, the native populations of Surakarta City are only 560,000 people (Setyowati et.al, 2020). It is due to many people from agglomeration area doing mobility to Surakarta City for occupational purpose, most of which use private vehicle. It can be seen from the increase in the number of private vehicle by over 200,000 vehicles annually in Surakarta City (Setyowati et.al, 2020). Considering the data released by the Central Bureau of Statistic (BPS) of Surakarta City, the number of motor vehicle ownership reached 26,556 in 2019, as shown in the table below.

Table 1.

Number of Motor Vehicles by Type in Surakarta City

\begin{tabular}{lc}
\hline \multicolumn{1}{c}{ Type } & Number \\
\hline Passenger Car & 5,432 \\
Bus Car & 46 \\
Freight Car & 811 \\
Motorcycle & 20,266 \\
Special Vehicle & 1 \\
Total & $\mathbf{2 6 , 5 5 6}$ \\
\hline
\end{tabular}

Source: Central Bureau of Statistic (BPS) of Surakarta City in 2019

In addition, technology development also results in transportation problem. It can be seen from the presence of online transportation services so that there is an increase in the number of private vehicles. Moreover, the number of online transportation drivers is more than that of service users. There have been 18,000 online transportation drivers up to 2017 in Solo Raya (Rozdianda, 2019). The presence of online transportation service is considered profitable to both driver and user as it can reduce unemployment rate and increase practicality 
to the community. However, it is a threat against the government as it makes people switch from public transportation to online transportation use.

Considering the problem, one of solutions taken is to provide adequate, comfortable public transportation. Urban public transportation plays a very important role in facilitating the people to do their activities in different locations in urban area. In addition to the large number of private vehicle ownership, the presence of urban public transportation is desirable to those having no private vehicle. The development of urban public transportation is directed to create credible service and to reduce people's dependence on the use of private vehicle.

Surakarta City is recorded to be one of cities to initiate the transformation of urban bus service into Bus Rapid Transit system (Transportologi, 2019). Surakarta City has provided public transportation called Batik Solo Trans managed by Damri since 2010. It is an early measure to improve public transportation, in which Surakarta City Government cooperates with several urban bus operators by establishing PT. Bengawan Solo Trans (Transportologi, 2019). Surakarta City also has reformed city transportation (angkot) in 2016 by establishing two cooperatives for city transportation (Transportologi, 2019). However, Surakarta City Government still faces other problems related to limited fund leading to the inhibited development of some sectors, including public service. For that reason, the City Government should cooperate with many parties to maximize public service. It is in line with Dwiyanto in Arsyiah \& Ramadhan (2021) stating that cooperation between government and nongovernment can improve the effectiveness of public service organizing cost. Cooperation or partnership model, according to Vestikowati (2012:69), can be an alternative solution to regional governments with limited capabilities particularly related to capital source, human resource, and management capability, so that the roles of investment, private business, and people become important to the regional economic development as the implication of the multidirectional regional autonomy.

The presence of new approach makes government no longer work alone, but through responsive government system called governance, by involving government, civil society, and private sector. The concept of governance emphasizes that there is no single organization in the organization of government and public service; partnership is needed with many parties, so that public service development is conducted using partnership governance or called public private partnership. There are some opinions on public private partnership, one 
of which is suggested by Linder \& Vaillancourt Rosenau in Korab-Karpowicz (2020:1) stating that public private partnership can be defined as "the establishment of cooperative relation between government, profit-oriented company, and not-for-profit private organization to fulfill the function of policy". In addition, according to Djabbari \& Thamrin (2021:2), Public Private Partnership (PPP) is the collaboration between government and private entity in providing infrastructure service and a way of getting additional funding source to infrastructural investment. Even, according to Yescombe in Nugroho (2012), the broadest definition of public private partnership involves the participation of non-government organization or institution in undertaking the governmental tasks. To ensure that the partnership program can run effectively, the principles of successful collaborative partnership according to Agarwal, Caiola, and Gibson (2015) is required, as illustrated below.

Figure 1.

\section{Prinsip Successful Collaborative Partnership}

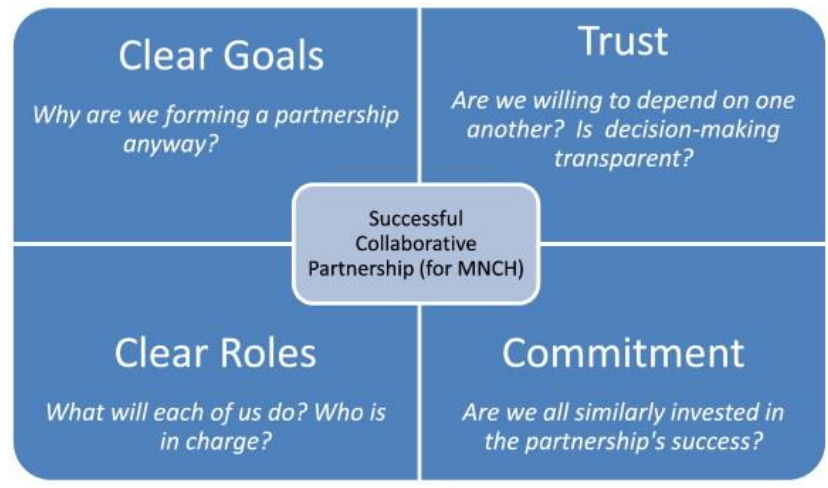

Source: Agarwal, Caiola, and Gibson (2015)

Based on the elaboration above, the measure taken by Surakarta City Government to serve the people through providing public transportation is to cooperate or to establish partnership with private sector as the provider of feeder and likewise, the central government. To provide innovative, sustainable public transportation facilities, a more reliable, comfortable, accessible and affordable public transportation should be developed. From the elaboration above, a problem can be formulated: "What is the Public Transportation Development in Surakarta City in Partnership Governance Perspective?" The objective of research is to find out the partnership performed by Surakarta City Government in the public transportation development in partnership governance perspective. 


\section{Methods}

The research method employed was qualitative one with descriptive approach. The research took place in Surakarta City, particularly in Transportation Office and Technical Executive Unit for Transportation in Transportation Office as the organizer of feeder along with Koperasi Trans Roda Sejati and Koperasi Bersama Satu Tujuan (Cooperatives). Informants were selected using purposive sampling technique, by means of selecting the informants knowing information and research problem in-depth. Data was collected through interview and documentation. Interview was conducted with Analyst of Land Transportation of Transportation Office, Chairperson of Transportation Office and Technical Executive Unit for Transportation in Transportation Office, Managers and Staffs of Human Resource Department of PT. Bengawan Solo Trans, PT. Trans Global Mandiri, and treasurer of Koperasi Bersama Satu Tujuan. Documentation was carried out by analyzing document of public transportation agreement such as Memorandum of Understanding (MoU). Data analysis referred to McNabb's (2010:31-37) thinking, consisting of 7 procedures: (1) identify the research problem; (2) establish research objectives; (3) decide on a research strategy; (4) prepare a research plan; (5) gather the data; (6) analyze and interpret the data; (7) prepare and present the findings.

\section{Results and Discussion}

Providing high-quality public transportation is one of obligations for the government to provide the best service to the public. Central and local governments should be mutually committed to satisfying the people's need for public transportation. Surakarta City feels this real form of governmental service. Central government, in this case Ministry of Transportation, provides public transportation service to regional government in synergy through transportation service operational grant from bus stop reform, subsidy of Batik Solo Trans service for free, etc. It is called "buy the service" scheme, i.e. the purchase of service by government to the private sector as the operator to operate Bus Rapid Transit (BRT). Batik Solo Trans is a public transportation system in the form of Bus Rapid Transit (BRT) to serve the people. Surakarta City is one of 5 (five) big cities in Indonesia to get operational grant from central government for public transportation in the region. This grant is inseparable from the cooperation with many parties, for example the operator of public transportation in Surakarta 
City including PT. Bengawan Solo Trans, PT. Trans Global Mandiri, and Koperasi Bersama Satu Tujuan. PT. Bengawan Solo Trans was established in 2013. This company is a consortium of 5 autobus companies (PO) in Surakarta: PO Nusa, PO Surya Kencana, PO Sumber Rahayu, PO Atmo, and PO Ska Jaya (Fitriyani \& Suharto, 2021). This company along with PT. Trans Global Mandiri and Bersama Satu Tujuan Cooperative becomes the operator of feeder and Batik Solo Trans. In this research, the partnership of public transportation development in Surakarta will be analyzed using Successful Collaborative Partnership theory from Agarwal, Caiola, and Gibson (2015), explained as follows.

1. Clear Goals

Clear goals in this case refer to agreement and explicit partnership to achieve the collective objective. The parties in partnership enter into agreement in order to achieve the collective objective. This principle enables the parties to know their own roles in achieving the objective.

In performing partnership, a certain party cannot run alone. The participation of parties is required to achieve the collective objective. Based on the Law No. 22 of 2009 about Traffic and Road Transportation, government is obliged to serve public transportation to the people. However, government cannot do so alone. For that reason, a partnership is required with other parties like public transportation business performers. Partnership in providing public transportation in Surakarta city has collective objective. Both Transportation Office and Technical Executive Unit for Transportation have main duties and functions to organize public transportation, to develop representative public transportation, and to serve Surakarta City people, which in turn create two grand designs. One is served by bus and another by feeder. In this case, assets belonging to Surakarta City government in public transportation sector are bus and feeder. The form of partnership in providing bus and feeder is performed by the operator, in this case PT. Bengawan Solo Trans as the provider of Batik Solo Trans bus, and PT. Trans Global Mandiri and Koperasi Bersama Satu Tujuan as the provider of feeder.

This partnership has basic objectives, among others: (1) to switch people from private to public transportation; and (2) to avoid or to reduce traffic jam. In addition to basic objective, there is another objective arising, i.e. to help people with no private transportation vehicle use public transportation for free. It is also mentioned in the Memoranda of Understanding between Surakarta City Government and PT. Bengawan Solo Trans Numbers 019.6/2320 and 
001/KS/PT.BST/VII/2013 about the Cooperation in Managing Road-Based Mass Transportation Service in Surakarta urban area. Considering the agreement, the parties provide road transportation infrastructure to the public constituting the government's duty and responsibility. Another partnership aims to improve public transportation service and its accessibility; therefore Government also establishes partnership along with Trans Roda Sejati and Bersama Satu Tujuan service cooperatives in providing Feeder. The partnership is regulated through: Agreement between Surakarta City Government and Trans Roda Sejati Cooperative Numbers: 119/860 and 002/Sek/TRS /III/2017 for providing feeder in corridors 9,11,14, and 15, and Agreement between Surakarta City Government and Bersama Satu Tujuan service cooperative Number: 119/860.1 and 088/BST/ III/2017 for providing feeder in corridors 8 and 13. The parties in the partnership have collective objective, to improve public service in the form of passenger transportation on the road with public transportation vehicle safely, comfortably, and affordably to the people.

\section{Clear Roles}

Clear roles emphasize on the clear contribution of individual parties in the partnership in order to achieve the collective success. Clear role distribution is very desirable to avoid job overlapping and duplication. This Batik Solo Trans partnership involves government, private, and cooperative. Government consists of central, provincial, and regional governments. Ministry of Transportation serves as central government, Transportation Office of Central Java Office as provincial government, and Transportation Office of Surakarta City and Technical Executive Unit for Transportation in Transportation Office of Surakarta City as regional government. Meanwhile, private sector involves PT. Bengawan Solo Trans and PT. Trans Global Mandiri. Cooperative involves public transportation one named Bersama Satu Tujuan cooperative. The role of individual parties in public transportation development in Surakarta is represented below.

Public transportation partnership in Surakarta City was begun in 2013 aiming to revitalize public transportation through improving bus fleet, route, payment model, and regulation of going up and down the bus stop. In that year, the government established partnership with PT. Bengawan Solo Trans only. The Partnership of Batik Solo Trans began to operate on February 24, 2014 with two corridors. As time goes by, 1 corridor was added in 2018. In early partnership, Batik Solo Trans is provided through investment subsidy scheme, in the sense of 
bus or fleet is provided by Transportation Office of Surakarta City. PT. Bengawan Solo Trans is the operator serving to assume the operational cost of Batik Solo Trans from 2014 through the middle of 2020. In this case, Batik Solo Trans bus vehicle is subsidized by Surakarta City Government, but any operational risk is assumed by PT. Bengawan Solo Trans. Furthermore, in the middle of 2020 - today central and provincial governments begin to be involved through "buy the service" program. Through this program, PT. Bengawan Solo Trans as the private sector should have capital for providing bus according to the specification specified by central government. Meanwhile, diesel fuel purchase and employee (driver and staff) recruitment monthly are assumed by central government.

Central Government, in this case the Ministry of Transportation through Directorate General of Land Transportation, is the one implementing "buy the service" program. "Buy the service" is the purchase of service by the government to the private sector as the operator which operates Bus Rapid Transit (BRT). Thus, Central Government provides full budget to implement "Buy the service" program, including driver salary, employee salary, spare part replacement, vehicle tax, motor vehicle inspection (KIR), full rent, monitoring facilities in the form of CCTV, and call center are all facilitated by Directorate General of Land Transportation, whose budget comes from APBN (State Income and Expenditure Budget). In this program, any risks are assumed by the government. Meanwhile, provincial government, in this case the Transportation Office of Central Java Province contributes to licensing affairs. Considering the Governor of Central Java's Regulation Number 69 of 2016 about Organization and Work Mechanism of Transportation Office of Central Java, the Transportation Office plays role and function in formulating and implementing policy in transportation field including, among others, road traffic and transportation, and train and shipping (Kristina et al, 2020). Furthermore, Surakarta City Government, in this case the Transportation Office, contributes to providing Batik Solo Trans infrastructures such as bus stops and traffic signs, planning and setting up trajectory, supervision and use, and operational policy. Meanwhile, Technical Executive Unit of Transportation serves to set up Standard Operating Procedure (SOP) and Standard Service Minimum (SPM), and to give building and education to drivers in order to provide the best service to the public.

PT. Trans Global Mandiri serves as the operator of feeder responsible fully for the management of feeder including employee recruitment and operational cost of vehicle. 
Meanwhile, Bersama Satu Tujuan cooperative is the partner of PT. Trans Global Mandiri serving as the operator providing feeder and driver. In this case, feeder substitutes for the city transportation vehicle (angkot), thereby the cooperatives for angkot are required to have their own public transportation vehicle to be revitalized into feeder later. About 120 city transportation vehicles from Bersama Satu Tujuan cooperatives have been revitalized into feeder up to 2021. Considering the figure, not all vehicles belonging to the Bersama Satu Tujuan cooperatives have been revitalized. Therefore, Bersama Satu Tujuan cooperatives propose 2 additional corridors for city transportation vehicle that have not been managed yet.

3. Trust

Trust is one of important elements to establish partnership. Trust can be built through communication and transparency in any thing, including decision making. The trust between the parties in the partnership can be established when government steps back and enables the private to fill in the role needed. In this case, the transfer or the fulfillment of role is a form of mutual trust in implementing a partnership.

Basically, this trust is established on the initiative of Surakarta City Government through Transportation Office which at that time implemented Batik Solo Trans program in 2010. In implementing the program, the Transportation Office of Surakarta City needs operator, so that it trusts fully the private to be the operator of Batik Solo Trans and feeder. The operator companies, including PT. Bengawan Solo Trans, PT. Trans Global Mandiri, and Bersama Satu Tujuan cooperatives, are intended to establish cooperation, to provide and to manage Batik Solo Trans and feeder bus services.

\section{Commitment}

Essentially, commitment can be established when one party prefers building partnership with another. Full commitment among the parties will result in an effective partnership. Strong commitment is very desirable to maintain and to improve the program in order to run according to the collective objective (Fitriyani \& Suharto, 2021).

Considering the result of interview, the parties in partnership including Transportation Office, Technical Executive Unit of Transportation, PT. Bengawan Solo Trans, PT. Trans Global Mandiri, and Bersama Satu Tujuan Cooperative are committed mutually to providing transportation infrastructure, managing, maintaining, and operating public transportation. 
The real form of commitment is, among others, manifested into the Memorandum of Understanding and consortium of 5 autobus companies. Ansell \& Gash in Fitriyani \& Suharto (2021) state that the presence of Memorandum of Understanding (MoU) and consortium is expected to remove the obstacles often appearing due to the difference of characteristics between stakeholders. In addition, the real form of commitment can be seen from the private sector contributing to the society through implementing Standard Operating Procedure (SOP) and Standard Service Minimum (SPM) specified by the Central Government. It is because they want to provide best service to the public, so that the people will be interested in using public transportation. Some measures have been taken to realize the commitment, one of which is to provide socialization to the potential users of feeder and Batik Solo Trans.

\section{Conclusion}

Considering the result of research, it can be concluded that public transportation in Surakarta was analyzed using 4 principles of Successful Collaborative Partnership from Agarwal, Caiola, and Gibson (2015): (1) Clear Goals: the Parties in partnership have collective objectives to improve public service in the form of passenger transportation on the road with public transportation vehicle safely, comfortably and affordably to the public; to switch the use of private vehicle to that of public transportation vehicle; to avoid and to reduce traffic jam; and to help people with no private vehicle use public transportation. (2) Clear Roles: Government is the party implementing "buy the service" program, contributing providing the full budget for implementing "buy the service" program. Provincial Government, in this case the Transportation Office of Central Java Province, contributes to licensing affairs. Transportation Office of Surakarta City contributes to providing Batik Solo Trans infrastructure. PT. Bengawan Solo Trans is the operator serving to assume the operational cost of Batik Solo Trans. PT. Trans Global Mandiri serves as the operator of feeder responsible fully for the management of feeder, including employee recruitment and operational cost of vehicle. Meanwhile, PT. Trans Global Mandiri serves as an operator providing feeder and driver. (3) Trust: Surakarta City government trusts fully the private to perform cooperation, to provide and to manage Batik Solo Trans and feeder bus service. (4) Commitment: Government and Private are committed mutually to providing transportation infrastructure, 
managing, maintaining, and operating public transportation as evidenced with Memorandum of Understanding (MoU) and consortium.

\section{References}

Agarwal, K., Caiola, N. \& Gibsonc, A. (2015). Best practices for a successful MNCH partnership that an external evaluation could never find: Experiences from the Maternal and Child Health Integrated Program. International Journal of Gynecology and Obstetrics. Vol. 130, pp. 11-16

Anis. (2021, Agustus 16). Personal Interview.

Arsyiah, W. O., \& Ramadhan, S. (2021). Implementation of Open Government Partnership in Public Information Services in Baubau City. Annals of the Romanian Society for Cell Biology, Vol. 25 (2), 2311-2316.

Badan Pusat Statistik. (2019). Jumlah Kendaraan Bermotor yang telah diregistrasi Menurut Jenis Kendaraan di Kota Surakarta 2019.

Dinas Perhubungan Provinsi Nusa Tenggara Barat. (2020). https://dishub.ntbprov.go.id/2020/12/08/peran-transportasi-terhadap-urbanisasi/

Djabbari, M. H., Alwi, A., \& Thamrin, S. H. (2021). Implementasi Public Private Partnership dalam Pengembangan Pariwisata di Kabupaten Toraja Utara. Jurnal Analisis Kebijakan E Pelayanan Publik (JAKPP), Vol. 7 (1), 1-13.

Fitriyani, E., \& Suharto, D. G. (2021). Collaborative Governance dalam Layanan Bus Rapid Transit di Kota Surakarta Tahun 2010-2019: Studi Tentang Kegagalan Kolaborasi. Journal of Government and Politics (JGOP), 3(1), 66-82.

Karno. (2021, September 11). Personal Interview.

Korab-Karpowicz, W. J. (2020). The United Citizens Organization: Public-Private Partnerships in Global Governance. Research in Globalization Journal, 2.

McNabb, D.E. (2010). Research Methods for Political Science: Quantitative and Qualitative Methods (2nd ed.). Routledge. https://doi.org/10.4324/9781315701141

Nugroho, R. (2012). Public Private Partnership as a Policy Dilemma. BISNIS \& BIROKRASI: Jurnal Ilmu Administrasi dan Organisasi, 18(3).

Riza. (2021, September 13). Personal Interview. 
Rozdianda, M. (2019). Persebaran Zona Merah Ojek Online di Surakarta. Doctoral dissertation, Universitas Muhammadiyah Surakarta.

Sadad. (2021, September 13). Personal Interview.

Setyowati, K, dkk. (2020). Strategic Planning on Smart Mobility Development. Jurnal Ilmu Sosial, Vol. 19 (2), 180-206.

Transportologi. (2019). Transportasi Kota Solo: Mencari Jalan Menuju Masa Depan. https://transportologi.org/laporan-transportologi/transportasi-kota-solo-mencarijalan-menuju-masa-depan/

Yanto. (2021, September 16). Personal Interview.

Yessi. (2021, September 13). Personal Interview.

Yulianto. (2021, Agustus 19). Personal Interview. 